\title{
Determination of the Species from Skeletal Remains Through Histomorphometric Evaluation and Discriminant Analysis
}

\author{
Determinación de la Especie a Partir de Restos Óseos \\ Mediante Evaluación Histomorfométrica y Análisis Discriminante
}

"Juan-Pablo Morales; *Ignacio Roa H.; ** Daniela Zavando \& ***Iván Suazo Galdames

MORALES, J. P.; ROA, H. I.; ZAVANDO, D. \& SUAZO, G. I. Determination of the species from skeletal remains through histomorphometric evaluation and discriminant analysis. Int. J. Morphol., 30(3):1035-1041, 2012.

SUMMARY: In situations where the skeletal remains found are too fragmented, it is necessary to assess the human origin of such remains; for this purpose, various parameters are used, both anatomical and histological. The objective of the present study is to evaluate the various histomorphometric parameters to differentiate human from non-human bones, to further construct discriminatory functions that allow interspecies classification. Tibia bones sections from human, bovine, pig, hen, cat, and dog species were used, processed through conventional histological techniques and observed under the microscope with a 40x magnification, analyzing the Haversian Canal Density parameters by $\mathrm{mm}^{2}$, Diameter of the Haversian Canal and the Diameter of the Haversian System which were compared through one way ANOVA with Scheffé post test, $\mathrm{p}<0.05$. Subsequently, the discriminatory functions were constructed for each species and the percentage of well-diagnosed cases was determined. Meaningful differences were found in the parameters analyzed; the discriminatory functions allowed to correctly classify $88.5 \%$ of the cases. Our results suggest that it is possible to differentiate human skeletal remains from non-human through the observation of their histological characteristics and histomorphometric parameters, but interspecies differentiation requires a more complex analysis.

KEY WORDS: Bone; Forensic analysis; Determination of species; Osteon compact bone; Haversian canal.

\section{INTRODUCTION}

Forensic Anthropology has among its objectives the study of skeletal remains to obtain personal identification, look for clues on the cause of death, determine age, race, sex, height of the subject, premortem bone injuries, and everything possible to collaborate with the law (Merabishvili, 2006; Suazo et al., 2009; Suazo \& Zavando, 2012).

In situations where the skeletal remains are too fragmented, forensic scientists are required to evaluate the human origin of these remains. Under such conditions, the analysis of macroscopic morphological characteristics is not enough to reach a diagnosis. For this reason, histological and biomolecular methods must be used, taking into consideration that the differences in the bone histological pattern among the various species have been known since the beginning of the century (Jowsey, 1966). As an example, we have the case of carnivores and rodents, which have more fragile spongy tissue in the articulatory regions of longer bones; specially of the humerus, femur and tibia. The destruction of these may complicate the diagnosis, thus preventing a timely decision in relation to whether a fragment is human or non-human (Saulsman et al., 2010).

There are various molecular and morphological methods available for the discrimination of species based on the skeletal structure. Measurable histological characteristics in the bone could help in the diagnosis; nevertheless, differences in the histological patterns along the whole skeleton, as well as those among different species, are not well documented (Saulsman et al.); therefore, it is relevant to record them, and adjust them to the local reality. Among the molecular techniques, we may find the protein radioinmunoassay (pRIA) and DNA analysis; nevertheless, even with the use of these new molecular approaches that offer a positive identification of fragments, histological techniques are needed to make the identification more timely and to help to rule out limitations such as the cost and time that these tests require (Saulsman et al.).

\footnotetext{
* Departamento de Ciencias Básicas Biomédicas, Universidad de Talca, Chile.

** Universidad Autónoma de Chile.

**** Facultad de Medicina, Universidad Diego Portales, Santiago, Chile.
} 
The currently accepted model of the compact bone organization is that of a system of longitudinal Canals called Haversian Canals, linked by cross-sectional connections (Volkmann Canals), which provide the blood flow that support the osteocytes in their function, all this inserted in a microstructural unit of the bone called Osteon (Pazzaglia et al., 2009). The measurement of Haversian Canals, together with parameters such as density and diameter of the osteons, among others, could aid in the diagnosis since it has been shown that the values obtained for the various species fall into different metric ranges (Cattaneo et al., 1999); in spite of this, it has to be taken into consideration that a number of factors influence the bone structure, including age, sex, size, mechanical stress to which the skeletal system underwent and diseases that might have affected it (Cuijpers, 2006).

Two lines of study were brought about in an effort to answer the human versus non-human question. The first line, and the oldest, is related to a detailed description of the cortical bone tissue of various species, whose outstanding contributors are Enlow \& Brown $(1957 ; 1958)$; who in spite of developing a good description, were not able to provide quantitative data on the histological patterns that differentiate human from nonhuman remains. Harsányi (1993), although more contemporary, is also considered in this line of study, but the difference lies in that he provided quantitative data about a histological structure, the aforementioned Haversian Canals; only missing to include data on specific characteristics of the Canals, such as direction, among others. The second line of study is concerned with the study of human bones comparing them with a small number of species, specially domestic animals and others, farm animal (Walter et al., 2004). Mulhern \& Ubelaker (2001), stated that through the observation of the compact Osteon of the femoral epiphysis of human adults and sub-adults, human skeletal remains could be differentiated from those of animals such as sheep and pigs. In addition, Whitman (2004), used as a sample rib bones of humans, of domestic animals such as dogs, and of farm animals such as pigs or cows, determining that the Haversian Canals have a greater diameter in humans; nevertheless, these measurements did not help to recognize a species in particular. In 2006, Merabishvili provided data on the Haversian Canals, assigning them characteristics such as: oval section, with rectilinear borders, anastomosed with one another, with diameters ranging from 30 to $150 \mu \mathrm{m}$ and densities from $8-10$ per $\mathrm{mm}^{2}$. On the side of the animal bone, the diameter would be less than $100 \mu \mathrm{m}$, finding higher densities per $\mathrm{mm}^{2}$ (13 a 55 per $\mathrm{mm}^{2}$ ). In the human bone the Canals are parallel to the longitudinal axis of the bone, and in animals these are slanted. The qualification and quantification of these differences are necessary in the evaluation of the bones, specially those fragmented, in order to make a specific identification of the species (Hensley, 2006).
Based on the background information aforementioned, the aim of the present study is to evaluate the most relevant histomorphometric methods to differentiate human skeletal remain from those of animals commonly found in our surroundings.

\section{MATERIAL AND METHOD}

A descriptive cross-sectional study design was used. The sample consisted of sections of tibia bone of six individuals of the following species: Human (Hommo sapiens sapiens), bovine (Bos taurus), pig (Sus scrofa domesticus), hen (Gallus gallus), cat (Felis catus), and dog (Canis familiaris).

The sample was obtained through dissection, with stereoscopic magnifier, of the lower limb (pelvic limb). After the exposure of the anterior border of the tibia, an excisional biopsy of full thickness in the anteromedial side of the bone, with characteristics of minimum extension $\left(1 \mathrm{~cm}^{2}\right)$ was performed. The samples obtained were fixed on Millonig formalin modified by Carlson $(\mathrm{pH}: 7.2$ and $0.1 \mathrm{M}$ in phosphate buffer), decalcified in $1 \%$ formic acid, and then processed through conventional histological technique, included in Paraplast Plus (Sigma); through this obtaining histological cuts: colored and of 5um in thickness, which were studied under a light microscope with a magnification of 40x.

The histological characteristics of the human bone and those of the 5 species were studied according to the description of Enlow \& Brown (1956). For this, an optical microscope Olympus BX40 (Olympus Corporation, Melville, NY) was used.

For each sample, the following quantitative parameters were studies:

1. Density of the Haversian Canal: The number of Haversian Canals found per $\mathrm{mm} 2$ was determined.

2. Diameter of the Haversian Canal: The greatest distance between the walls of the Haversian Canal expressed in $\mu \mathrm{m}$ was determined.

3. Diameter of the Haversian System (Osteon): The greatest distance between the walls of an osteon expressed in $\mu \mathrm{m}$ was determined.

For the quantitative parameters, the descriptive statistics were calculated with values of central tendency and dispersion values. For the comparison of the parameters among the species, the variance analysis (ANOVA) with Scheffé post test was used. In all the cases, the $\mathrm{p}$ value was 
0.05 with a confidence interval of $95 \%$. Following, with the help of the statistical software SPSS 15.0, an exploratory discriminant analysis was performed, including the classification functions for each species, thus determining the percentage of well-classified cases.

The sample corresponds to compact bone tissue cuts, subject to demineralization and labeled according to the species, which present the following characteristics:

\section{RESULTS}

Histological Analysis. Human Bone: Presented a characteristic organization, compact osteons with a central canal with cellular and vascular elements. The osteons were easily identified and delimited due to the presence of clear and well-defined cement lines with the presence of osteocytes in their corresponding lacunas. (Fig.1).

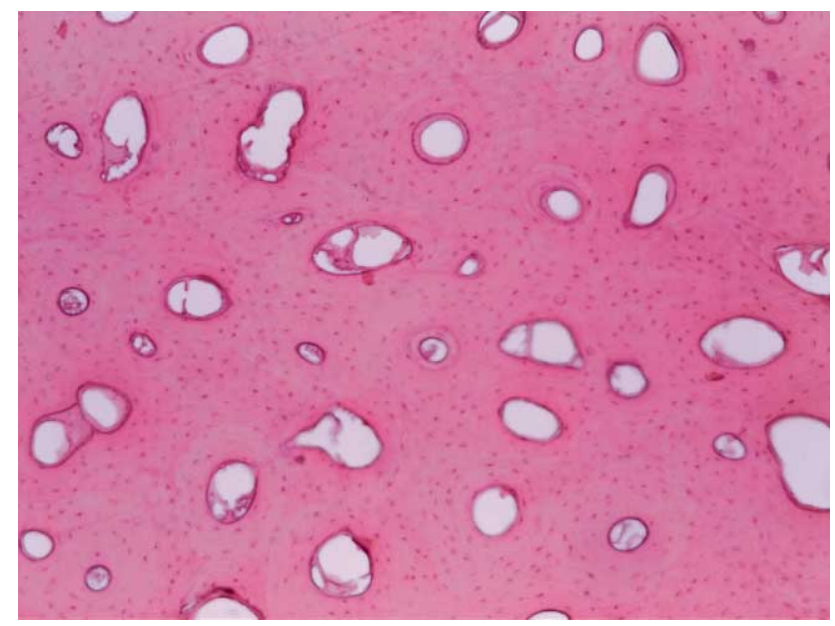

Fig. 1. Human bone photomicrography obtained with HE technique, increased 40X.

Bovine Bone: This type of bone tissue is the one that on observation is the closest to the human bone tissue, its osteons are more oval (compared to the human ones) and the borders are not well defined. (Fig.2).

Canis Bone: It has a high density of medium size osteons per $\mathrm{mm} 2$, with a great amount of interstitial systems among them. (Fig.3).

Pig Bone: In comparison with the characteristics of the human bone, it presents a lower number of osteons per $\mathrm{mm}^{2}$, these being slightly bigger, more irregular and with borders not well defined. There is presence of osteocytes surrounded by their characteristic lacunas. (Fig.4).

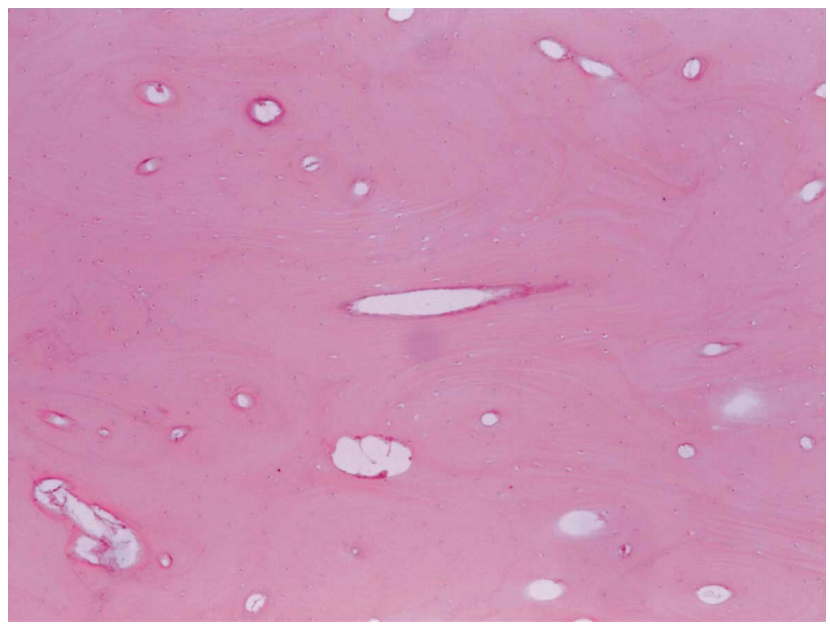

Fig. 2. Bovine bone photomicrography obtained with HE technique, increased 40X.

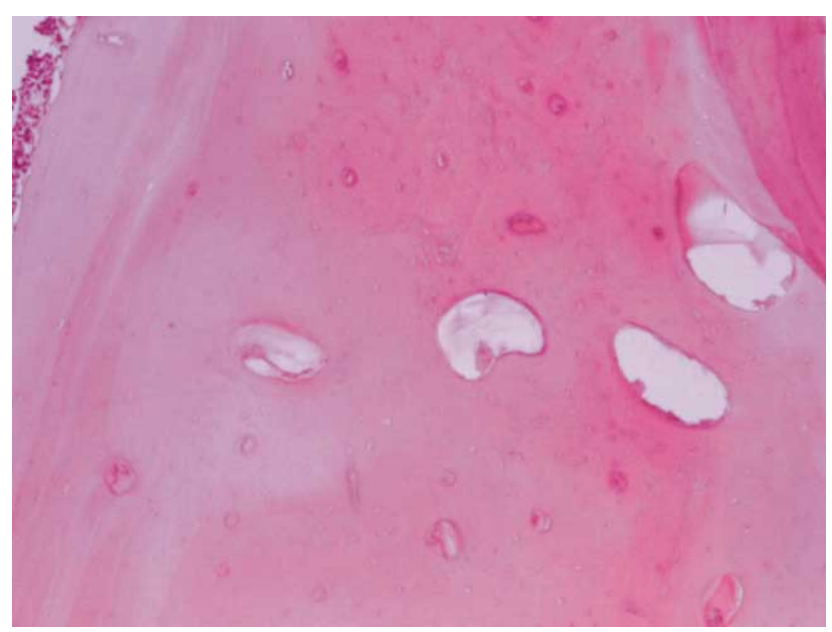

Fig. 3. Dog bone photomicrography obtained with HE technique, increased 40X.

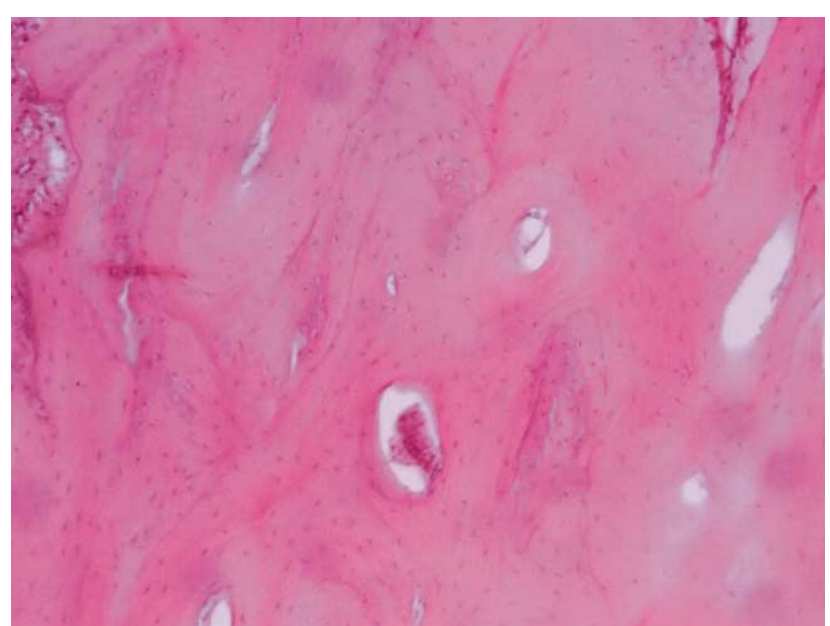

Fig. 4. Pig bone photomicrography obtained with HE technique, increased $40 \mathrm{X}$. 
Hen Bone: High density of small size osteons per $\mathrm{mm}^{2}$, accompanied by scarce interstitial systems. (Fig.5).

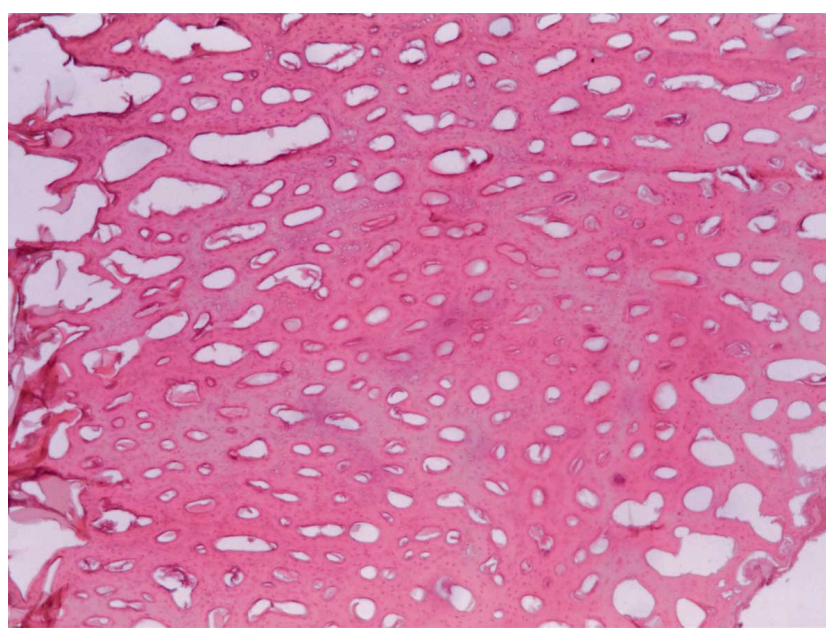

Fig. 5. Hen bone photomicrography obtained with HE technique, increased 40X.
Cat Bone: It has a high density of medium size osteons, with a great amount of interstitial systems among them. (Fig.6).

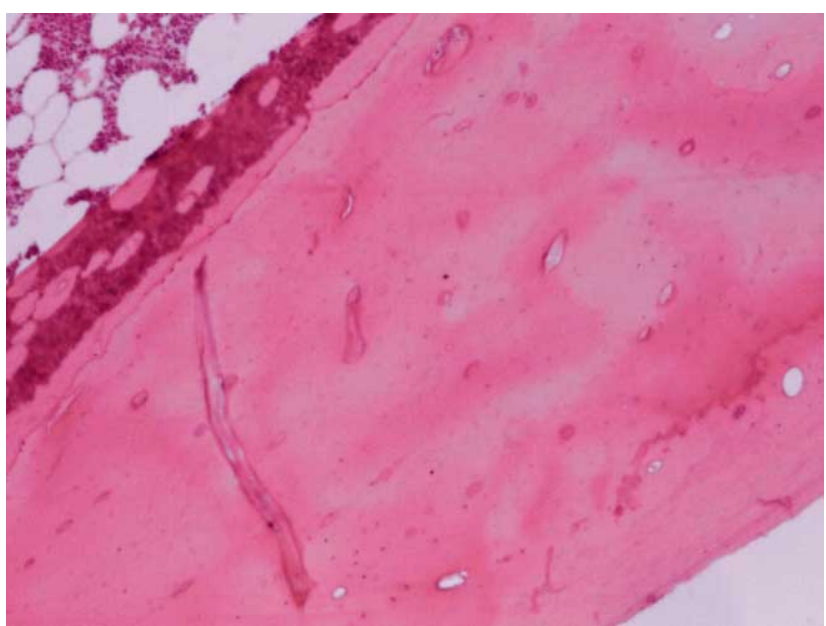

Fig. 6. Cat bone photomicrography obtained with HE technique, increased 40X.

Table I. Descriptive statistics for the canal diameter. diameter of the osteon and the density of the canal per $\mathrm{mm}^{2}$ variables.

\begin{tabular}{|c|c|c|c|c|c|}
\hline & & Mean & SD & Min & Max \\
\hline \multirow[t]{7}{*}{ Canal diameter $\mu \mathrm{m}$} & Human & 35.92 & 2.12 & 33.90 & 38.90 \\
\hline & Dog & 12.37 & 1.91 & 10.94 & 15.02 \\
\hline & Cat & 10.60 & 1.01 & 9.78 & 11.97 \\
\hline & Pig & 40.09 & 14.82 & 29.61 & 61.24 \\
\hline & Bovine & 26.24 & 3.75 & 21.66 & 30.50 \\
\hline & Hen & 29.49 & 2.18 & 27.34 & 33.15 \\
\hline & Total & 25.94 & 12.16 & 9.78 & 61.24 \\
\hline \multirow[t]{7}{*}{ Diameter of the osteon $\mu \mathrm{m}$} & Human & 111.07 & 2.25 & 108.51 & 113.99 \\
\hline & Dog & 59.39 & 3.63 & 54.63 & 63.38 \\
\hline & Cat & 49.93 & 3.29 & 47.47 & 54.45 \\
\hline & Pig & 114.76 & 8.19 & 106.07 & 125.82 \\
\hline & Bovine & 118.34 & 16.40 & 94.80 & 140.28 \\
\hline & Hen & 45.73 & 4.66 & 38.90 & 50.06 \\
\hline & Total & 83.11 & 33.72 & 38.90 & 140.28 \\
\hline \multirow[t]{7}{*}{ Density of the canal per $\mathrm{mm}^{2}$} & Human & 6.23 & 0.30 & 5.99 & 6.62 \\
\hline & Dog & 8.75 & 0.47 & 8.20 & 9.14 \\
\hline & Cat & 8.28 & 1.63 & 7.25 & 10.72 \\
\hline & Pig & 1.97 & 0.39 & 1.57 & 2.52 \\
\hline & Bovine & 3.65 & 0.65 & 2.83 & 4.41 \\
\hline & Hen & 19.36 & 1.25 & 17.66 & 20.82 \\
\hline & Total & 8.31 & 6.05 & 1.57 & 20.82 \\
\hline
\end{tabular}


Quantitative Analysis. The detail of the results of the quantitative parameters analyzed may be found in Table I.

For the variable Haversian Canal diameter, the human bone was significantly different to the bone of the dog and cat, but not to that of the pig, bovine and hen; while for the variable Osteon diameter, the human bone was significantly different to the bone of the dog, cat and hen, but not to the pig and bovine bone; and in reference to the of Haversian
Canals per mm2, the human bone was significantly different to that of the dog, pig, bovine and hen, but not to that of the cat (Tables II, III and IV).

Discriminant Analysis. With the data obtained, the discriminant linear functions for the diagnosis of the species were built. This may be observed in Table V. The functions constructed allowed $88.5 \%$ of the cases to be successfully classified. (Table VI).

Table II. Results of one way ANOVA analysis and Scheffé post test. comparing the values obtained for the Haversian Canal diameter variable in human bone. with those obtained in the other five species included in the analysis.

\begin{tabular}{ccccc}
\hline & Specie & Mean differences & $\begin{array}{c}\text { Typical } \\
\text { error }\end{array}$ & Sig. \\
\hline Human & Dog & $23.55^{*}$ & 4.36 & .002 \\
& Cat & $25.32^{*}$ & 4.36 & .001 \\
& Pig & -4.16 & 4.36 & .966 \\
& Bovine & 9.68 & 4.14 & .394 \\
& Hen & 6.43 & 4.14 & .784 \\
\hline
\end{tabular}

* The mean differences was significant with $\mathrm{p}<0.05$.

Table III. Results of one way ANOVA analysis and Scheffé post test. comparing the values obtained for the Osteon diameter variable in human bone. with those obtained in the other five species included in the analysis

\begin{tabular}{lcccc}
\hline & Specie & Mean differences & $\begin{array}{c}\text { Typical } \\
\text { error }\end{array}$ & Sig. \\
\hline Human & Dog & $51.68^{*}$ & 6.02 & .000 \\
& Cat & $61.14^{*}$ & 6.02 & .000 \\
& Pig & -3.69 & 6.02 & .995 \\
& Bovine & -7.27 & 5.71 & .893 \\
& Hen & $65.33^{*}$ & 5.71 & .000 \\
\hline
\end{tabular}

* The mean differences was significant with $\mathrm{p}<0.05$.

Table IV. Results of one way ANOVA analysis and Scheffé post test. comparing the values obtained for the Haversian Canal density per $\mathrm{mm}^{2}$ variable in human bone. with those obtained in the other five species included in the analysis.

\begin{tabular}{ccccc}
\hline & Specie & Mean differences & $\begin{array}{c}\text { Typical } \\
\text { error }\end{array}$ & Sig. \\
\hline Human & Dog & $-2.52^{*}$ & 0.66 & .039 \\
& Cat & -2.05 & 0.66 & .135 \\
Pig & $4.25^{*}$ & 0.66 & .000 \\
& Bovine & $2.57^{*}$ & 0.62 & .023 \\
& Hen & $-13.13^{*}$ & 0.62 & .000 \\
\hline
\end{tabular}

\footnotetext{
* The mean differences was significant with $\mathrm{p}<0.05$.
} 
Table V. Classification functions for the identification of the 6 species analyzed for the variables of Haversian Canals diameter. Osteon diameter. and density of the Haversian Canal per $\mathrm{mm}^{2}$.

\begin{tabular}{|c|c|}
\hline Human & $\mathrm{Y}=-109.382+0.462 \times \mathrm{xC}+1.397 \times \mathrm{xO}+6.936 \mathrm{xDm}^{2}$ \\
\hline Dog & $\mathrm{Y}=-68.023+0.163 \mathrm{xDC}+0.739 \mathrm{xDO}+9.870 \mathrm{xDmm} 2$ \\
\hline Cat & $\mathrm{Y}=-59.798+0.163 \mathrm{xDC}+0.611 \mathrm{xDO}+9.374 \mathrm{xDmm} 2$ \\
\hline Pig & $\mathrm{Y}=-97.506+0.469 \mathrm{xDC}+1.468 \times \mathrm{xDO}+2.035 \mathrm{xDmm} 2$ \\
\hline Bovine & $\mathrm{Y}=-103.817+0.76 \mathrm{xDC}+1.596 \times \mathrm{xDO}+3.666 \mathrm{xDmm}{ }^{2}$ \\
\hline Hen & $Y=-243.370+0.981 \times D C+0.316 x D O+22.720 x D m m^{2}$ \\
\hline
\end{tabular}

Table VI. Results of the classification (\%) from the functions described in Table V show that $88,5 \%$ of the cases were successfully classified.

\begin{tabular}{lccccccc}
\hline \multicolumn{7}{c}{ Predicted group membership } \\
\hline Human & Human & Dog & Cat & Pig & Bovine & Hen & Total \\
Dog & 100.0 & 0 & 0 & 0 & 0 & 0 & 100.0 \\
Cat & 0 & 100.0 & 0 & 0 & 0 & 0 & 100.0 \\
Pig & 0 & 25.0 & 75.0 & 0 & 0 & 0 & 100.0 \\
Bovine & 0 & 0 & 0 & 75.0 & 25.0 & 0 & 100.0 \\
Hen & 0 & 0 & 0 & 20.0 & 80.0 & 0 & 100.0 \\
& 0 & 0 & 0 & 0 & 0 & 100.0 & 100.0 \\
\hline
\end{tabular}

\section{DISCUSSION}

The various histomorphometric parameters may have a high value in the scope of the forensic investigation. In our study, we confirmed the presence of morphometric differences in the morphological parameters of the bone in different species, which allowed to differentiate the human bone from those of other species, with these data we constructed the discriminant functions through which we obtained a $88.5 \%$ precision for the diagnosis of the species.

Our results are in line with those reported by Cattaneo et al. who were able to differentiate human from non-human skeletal remains using similar characteristics to those of the present study. These authors obtained a 79\% correct classification of the cases, but it is important to point out that their study was done under the condition of burned bones which may have affected the size of the parameters used in the study. Mulhern was able to differentiate skeletal remains using femoral diaphysis sections of humans, pigs and sheep comparing the presence of osteon bands, their characteristics and measurements, and achieved to successfully differentiate human bones from those of animals, but did not determine the species. Whitman (2004) and later Cuijpers differentiates human from non-human bones, but states that it interspecies differentiation is not possible. Martiniakova et al. (2005) achieved to differentiate, using the parameters of osteons and Haversian Canals diameter, human bones from those of 5 species: bovine, pig, rabbit, sheep and rat, but opposed to the studies already mentioned, discriminant analysis was used to classify the different species. As a result of this analysis, the following classifications were achieved: $100 \%$ for human, $78.54 \%$ for bovine, $42.67 \%$ for pig, $86.47 \%$ for rabbit $57.33 \%$ for sheep; which provides evidence that the parameters used are meaningful to solve the problem of whether skeletal remains correspond to the human species or not.

The results of the present study suggest that it is possible to differentiate human skeletal remains from nonhuman ones through the observation of their histological characteristics and histomorphometrical parameters, but the interspecies differentiation requires a more complex analysis. 
MORALES, J. P. ROA, H. I.; ZAVANDO, D. \& SUAZO, G. I. Determinación de la especie a partir de restos óseos mediante evaluación histomorfométrica y análisis discriminante. Int. J. Morphol., 30(3):11035-1041, 2012.

RESUMEN: En situaciones donde los restos óseos que se encuentran están muy fragmentados, es necesario evaluar el origen humano de dichos restos, para ello se utilizan diversos parámetros morfológicos tanto anatómicos como histológicos. El propósito de este estudio fue evaluar los distintos parámetros histomorfométricos para diferenciar hueso humano de no humano, para posteriormente construir las funciones discriminantes que permitan la clasificación interespecies. Se utilizaron secciones de hueso de tibia de individuos de especies: humano, bovino, cerdo, gallina, gato y perro, procesadas mediante técnica histológica convencional y observadas al microscópio con aumento 40x, analizándose los parámetros Densidad del canal de Havers por $\mathrm{mm}^{2}$, Diámetro del canal de Havers y diámetro del sistema Haversiano, los cuales fueron comparados mediante one way ANOVA con Scheffé post test con $\mathrm{p}<0,05$. Posteriormente se construyeron las funciones discriminantes para cada especie y se determinó el porcentaje de casos bien diagnosticados. Se encontraron diferencias significativas en los parámetros analizados, las funciones discriminantes permitieron la correcta clasificación del $88,5 \%$ de los casos. Nuestros resultados sugieren que es posible diferenciar restos óseos humanos de no humanos mediante la observación de sus características histológicas y parámetros histomorfométricos, pero la diferenciación interespecie requiere de análisis más complejo.

PALABRAS CLAVE: Hueso; Análisis forense; Determinación de la especie; Osteona compacta; Canal de Havers.

\section{REFERENCES}

Cattaneo, C.; DiMartino, S.; Scali, S.; Craig, O. E.; Grandi, M. \& Sokol, R. J. Determining the human origin of fragments of burnt bone: a comparative study of histological, immunological and DNA techniques. Forensic Science International, 102(2-3):18191, 1999.

Cuijpers, A. Histological identification of bone fragments in archaeology: telling humans apart from horses and cattle. Int. J. Osteoarchaeol., 16:466, 2006.

Enlow, D. \& Brown, S. A comparative histological study of fossil and recent bone tissue, part II. Tex. J. Sci., 9(2):186-214, 1957.

Enlow, D. \& Brown S. A comparative histological study of fossil andrecent bone tissue, part III. Tex. J. Sci., 10(2):187-230. 1958.

Harsányi, L. Differential diagnosis of human and animal bone. In: Grupe, G. \& Garland, A. N. (eds) Histology of Ancient Bone: Methods and Diagnosis. Berlin: Springer, 1993. pp. 79-94.

Hensley, Z. Quantitative and spatial analysis of the microscopic bone structures of deer (Odocoileus Virginanianus), dog (Canis Familiaris), and pig (Sus Scrofa Domesticus). A Thesis Submitted to the Graduate Faculty of the Louisiana State University and Agricultural and Mechanical College in partial fulfillment of the requirements for the degree of Master of Arts in The Department of Geography and Anthropology, ix. 2006.

Jowsey, J. Studies of Haversian systems in man and some animals, J. Anat., 100:857-64, 1966.

Martiniakova, M.; Omelka R; Chrenek, P.; Vondrakova, M. \& Vauerova, M. Age related changes in histological structure of the femur in juvenile and adult rabbits: a pilot study. Bull. Vet. Inst. Pulawy., 4:227-30, 2005.

Merabishvili, G. Superposición de Imágenes Identificación Facial Bidimensional. Universidad de Barcelona, facultad de medicina, departamento de Salud Pública, memoria para optar al grado de doctor, 2006.
Mulhern, D. \& Ubelaker, D. Differences in osteon banding between human and nonhuman bone. J. Forensic Sci., 46:220-2, 2001.

Pazzaglia, E.; Congiu, T.; Raspanti, M.; Ranchetti, F. \& Quacci, D. Anatomy of the Intracortical Canal System Scanning Electron Microscopy Study in Rabbit Femur. Clin Orthop Relat Res., 467:2446-56, 2009.

Saulsman, B.; Oxnard, C. \& Franklin, D. Long bone morphometrics for human from non-human discrimination. Forensic Science International, 202:110.e1-5, 2010.

Suazo, G. I.; Zavando, M. D. \& Smith, R. L. Performance evaluation as a diagnostic test for traditional methods for forensic identification of sex. Int. J. Morphol., 27(2):381-6, 2009.

Suazo, G. I. \& Zavando, D. Age effect in the morphological traits performance for determination in human skulls and mandibles. Int. J. Morphol., 30(1):296-301, 2012.

Walter, T.; Paine, R. \& Horni, H. Histological examination of bonetempered pottery from mission Espíritu Santo (41VT11), Victoria County, Texas. J. Arch. Sci., 31:393-8, 2004.

Whitman, E. Differentiating between human and non-human secondary osteons in human, canine and bovine rib tissue. East Lansing, MI: Michigan State University, 2004.

\section{Correspondence to:}

Prof. Dr. Iván Suazo Galdames

Department of Morphofunction

Faculty of Medicine

Universidad Diego Portales

Santiago

CHILE

Email: ivan.suazo@udp.cl

Received: 12-04-2012

Accepted: 27-06-2012 